\title{
The Effects of Fire on Surface-Dwelling Arthropod Communities in Pinus brutia Forests of Southwestern Anatolia
}

\author{
Burçin Yenisey KAYNAŞ ${ }^{1}$
}

\begin{abstract}
This study aimed at exploring the response of surface-active arthropod communities to fire and fire-induced habitat alteration in a Pinus brutia Ten. forests in southwestern Turkey. Samplings were carried on in twelve study sites by using 36 pitfall traps in burned and unburned sites during two months immediately after fire occurred in August 2004. According to results obtained in two sampling terms, the abundances of all arthropods, insects and ants were higher on the burned site than on the unburned site. The other community parameters such as species richness, diversity and evenness were found higher in the burned site for insects and ants. Diptera that was represented mostly by one species, the syrphid fly Eumerus strigatus (Fallen, 1817) was caught in great abundance in the burned site. Colonizing of Orthotomicus erosus (Wollaston, 1857) at burned site in two months after fire increased abundance of bark beetles in the burned site rapidly. Consequently, it was not determined destructive effects of fire on abundance of arthropods in spite there were changes in community structures depending on rapid habitat alterations.
\end{abstract}

Keywords: Arthropods, East Mediterranean, Forest Fires, Insects, Recovery

\section{Güneybatı Anadolu Pinus brutia Ormanlarında Orman Yangınlarının Yüzey-Aktif Eklembacaklı Komüniteleri Üzerine Etkisi}

ÖZET: Bu çalışma, Güneybatı Anadolu Pinus brutia Ten. ormanlarında yangının ve yangın kaynaklı habitat değişiminin yüzey-aktifeklembacaklı komüniteleriüzerine etkilerinin araştırılmasını amaçlamıştır. Eklembacaklılara yönelik örnekleme çalışmaları, 2004 yılının Ağustos ayında meydana gelen bir orman yangının hemen sonrasında yanmış ve yanmamış alanlardan seçilen, 12 çalışma alanında 36 çukur tuzak kullanılarak, iki aylık dönem boyunca gerçekleştirilmiştir. Çalışmanın sonucuna göre, eklembacaklıların (Şube: Arthropoda), böceklerin (Sınıf: Insecta) ve karıncaların (Familya: Formicidae) bolluk değerlerinin her iki örnekleme döneminde de yanmış alanda yanmamış alana gore daha yüksek olduğu tespit edilmiştir. Böcekler ve karıncalar için hesaplanan tür zenginliği, tür çeşitliliği ve eşitlik değerleri yanmış alanda yanmamış alana gore daha yüksektir. Büyük oranda; Eumerus strigatus (Fallen, 1817) türü ile temsil edilen Diptera Takımı, yanmış alanda yüksek bolluk değerine sahiptir. Yangın sonrası ikinci ayda Orthotomicus erosus (Wollaston, 1857)'un yanmış alanda gerçekleşen kolonizasyonu, kabuk böceklerinin bu alandaki bolluğunun ani bir şekilde artmasına neden olmuştur. Sonuç olarak, yangın sonrası ani habitat değişimine bağlı olarak eklembacaklı komünitelerinin yapısında önemli değişimler meydana gelmesine rağmen, yangının arthropod komüniteleri üzerinde yıkıcı bir etkisi tespit edilmemiştir.

Anahtar Kelimeler: Arthropoda, Doğu Akdeniz, Böcek, Orman Yangınları, Yenilenme

Mehmet Akif Ersoy Üniversitesi, Fen-Edebiyat Fakültesi, Biyoloji Bölümü, Burdur, Türkiye

Sorumlu yazar/Corresponding Author: Burçin Yenisey KAYNAŞ, bykaynas@mehmetakif.edu.tr 


\section{INTRODUCTION}

Fire is an integral part of many ecosystems in the world such as Mediterranean and it serves as a strong selective force on plant and animal communities (Thanos and Marcou, 1989). Its effects on biota can be considered in terms of immediate, short-term and longterm effects. Two main immediate effects are removal of vegetation depends on a number of factors encapsulated in the intensity of the fires and the chemical properties of the vegetation (Fox and Fox, 1987). Additionally, direct effects may vary widely depending on weather conditions, stand characteristics and the characteristics of the fire itself (Wikars and Schimmel, 2001). In animals, the sensivity to fire depend on several biological characteristics: trophic level, seasonal activity and vertical distribution (Prodon et al., 1987). Immediate effects of fire on forest arthropods may occur by the way of direct mortality (Paquin and Coderre, 1997), forced migration out of a habitat (Kim and Holt, 2012) and attraction to post-fire areas (Wikars, 1992). Many insect groups decline markedly immediately after fire, with the magnitude of reduction related to the degree of exposure to the heat and mobility of the insect. By contrast, many insect species in variety of families are attracted by fire or smoke or oviposition site freshly burned wood or soil (Swengel, 2001).

In Mediterranean ecosystems there are a few studies about short and longer term changes of arthropod groups after fire (Sgardelis et al., 1995; Broza and Izhaki, 1997; Radea and Arianoutsou, 2000; Kaynaş and Gürkan, 2007; 2008). However, the knowledge about immediate effects is very limited. In this study, it was aimed to investigate immediate changes in a recently burned $P$. brutia forest in terms of the arthropod community. We asked 1) to what extent are burned sites used by surface active arthropods right after fire; 2) which organism groups are found in recently burned sites, and; 3) how changes the abundance in arthropod groups recently after fire?

\section{MATERIAL AND METHODS}

The study site was located in Marmaris National Park in Marmaris District, Muğla Province (36 $52^{\prime} 05^{\prime \prime}$ K, $2816^{\prime} 40^{\prime \prime}$ E). The National Park covers 29,206 ha area and its natural habitats comprise mostly mosaic structure of post-fire Pinus brutia forests at different ages. This area has a typical Mediterranean climate with a hot and dry summer. Total precipitation 1211.7 $\mathrm{mm} \mathrm{yr}^{-1}$ (between 1975 and 2006), dry period continues 5 months between May and September. Mean monthly temperatures range from $10.6 \mathrm{C}^{\circ}$ in January to $28.3 \mathrm{C}^{\circ}$ in July.

The predominant vegetation type of the study site before fire was P. brutia forest. The understory vegetation consists of Genista acanthoclada DC., Myrtus communis L., Phyllarea latifolia L., Erica manipluflora Salisb., and Quercus coccifera L. species.

The study was carried out after a crown fire which occurred on 20-21 August 2004. In the fire, 7 ha $P$. brutia forest stretching from an altitude of 80 to 300 $\mathrm{m}$ was totally burned through. Six study sites (total 12 sites) were chosen randomly in burned and unburned sites. These sites were not further away than $100 \mathrm{~m}$ from the border between burned and unburned forest. In each site 3 pitfall traps were established with $5 \mathrm{~m}$ intervals. Pitfall traps (plastic cup, $7 \mathrm{~cm}$ in diameter and $10 \mathrm{~cm}$ in depth) were buried in the ground with the rim at the surface level and filled with $4 \%$ formaldehyde solution. Trapping was conducted in two months long sessions after fire $\left(22^{\text {nd }}\right.$ Aug. to $23^{\text {rd }}$ Sept. and $23^{\text {rd }}$ Sept. to $23^{\text {rd }}$ Oct. in 2004).

The pit-fall samples were processed in the lab. In the laboratory; we recorded the number of individuals for each morphospecies of orders. Species level identification could be performed for some orders. Mean number of three pitfall traps for each sampling site was used for statistical calculations.

Species richness as expression of number of species and evenness were calculated. Similarity among study sites and species diversity were estimated by Morisita similarity index and Shannon's diversity index $\left(\mathrm{H}^{\prime}\right)$, respectively. Student's t-test was used for normally distributed data, and the Mann-Whitney U-test otherwise.

\section{RESULTS AND DISCUSSION}

The total catches of arthropods, belonging to three taxa Arachnida, Chilopoda and Insecta in the burned and unburned sites were 861 and 544 individuals 
respectively. The majority of the caught arthropods were insects. The insect abundance displayed similarity to arthropod abundance, with 832 and 505 individuals respectively in burned and unburned sites (Figure 1.). In both sampling periods total abundancy values of arthropods and insects were high in the burned site than unburned site as could be noticed in the Table 1. However, the difference between burned and unburned sites in the second sampling period was more conspicuous and significant statistically (Total arthropod, $\mathrm{t}=3.446 ; \mathrm{p}=0.024 ; \mathrm{n}=12$; insects, $\mathrm{t}=3.495$; $\mathrm{p}=0.027 ; \mathrm{n}=12)$. Even though, difference between burned and unburned sites in terms of number of insects became higher depending on time since fire, similarity between insect communities of these sites displayed increase. Insect communities were more similar in the second sampling period than shortly after fire. In addition to this, similarity was higher between burned and unburned sites in both sampling periods than between sampling periods (Figure 2.). Regarding the other community parameters, estimated species diversity $\left(\mathrm{H}^{\prime}\right)$ and evenness values in all pairwise comparisons showed that, burned sites had more diverse insect community than unburned sites (Table 1.).
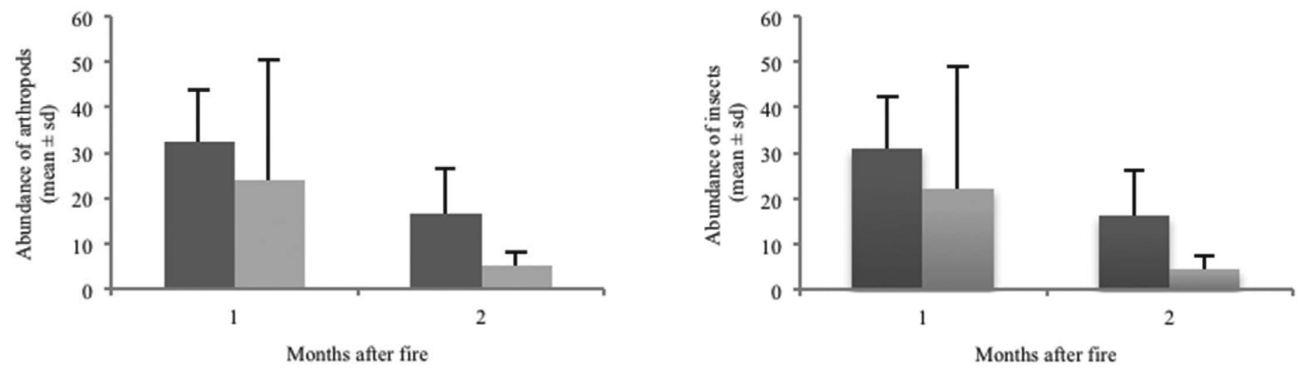

Figure 1. Arthropod and insect abundances of study sites in burned (darker bar) and unburned sites (lighter bar).
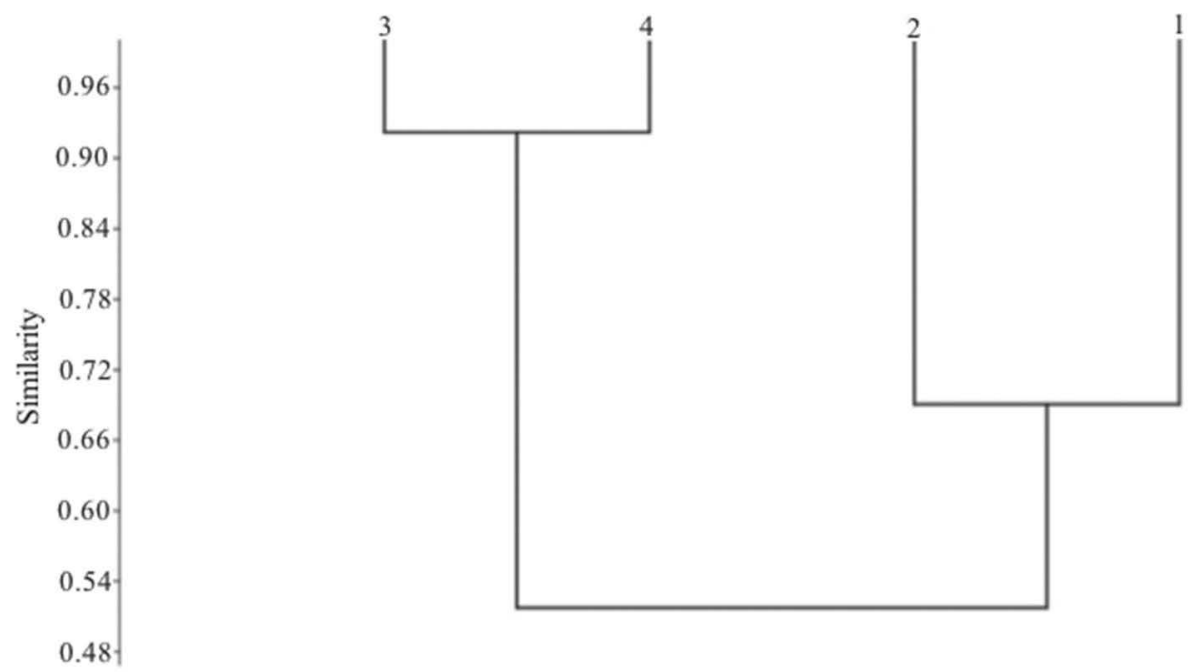

Figure 2. Similarity (Morisita similarity index) between burned and unburned sites in two sampling periods (1- burned site in the first sampling period, 2- unburned site in the first sampling period, 3- burned site in the second sampling period, 4- unburned site in the second sampling period). 
Table 1. Species diversity and evenness of ants and other insects in burned and unburned sites.

\begin{tabular}{lllll} 
& \multicolumn{3}{c}{ 2 months later } \\
\cline { 2 - 4 } & Burned & Unburned & Burned & Unburned \\
\hline All insects & & & & 0.2947 \\
Evenness & 0.3188 & 0.3022 & 0.3644 & $1.759^{\mathrm{b}}$ \\
Species diversity $\left(\mathrm{H}^{\prime}\right)$ & $2.035^{\mathrm{a}}$ & $1.774^{\mathrm{b}}$ & $1.774^{\mathrm{b}}$ & 0.498 \\
Ants & & & & $0.9994^{\mathrm{c}}$ \\
Evenness & 0.4787 & 0.4414 & 0.54 & $1.156^{\mathrm{c}}$ \\
Species diversity $\left(\mathrm{H}^{\prime}\right)$ & $1.661^{\mathrm{a}}$ & $1.500^{\mathrm{b}}$ & & \\
\hline
\end{tabular}

(Different superscript letter in the same row denotes significant differences between sites $\mathrm{p}<0.05$ )

Some insect orders such as Blattodea, Hemiptera, Neuroptera, and Orthoptera were represented by small numbers of individuals. Blattodea represented by just a species, Blatta orientalis Linnaeus, 1758, has high abundancy in the unburned site in first month after fire. On the contrary, Hemiptera was a group abundant in the burned site of same term (Table 2.). Their abundances were not evaluated statistically because of too low numbers. Hymenoptera order consists of mostly ants
(98\%). Ants were the most abundant group in all study sites. Their abundances in burned and unburned sites was close in the first sampling period, but there was significantly more individuals in the burned site in second sampling period $(\mathrm{p}=0.004 ; \mathrm{t}=3.588 ; \mathrm{n}=12)$ (Figure 3.). Species diversity and evenness values belong to this group were higher in the burned site compare with unburned site for both sampling periods (Table 1.)

Table 2. Abundances and species richness of insect orders caught in burned and unburned sites.

\begin{tabular}{|c|c|c|c|c|c|c|c|c|}
\hline & \multicolumn{4}{|c|}{1 month later } & \multicolumn{4}{|c|}{2 months later } \\
\hline & \multicolumn{2}{|c|}{ Burned } & \multicolumn{2}{|c|}{ Unburned } & \multicolumn{2}{|c|}{ Burned } & \multicolumn{2}{|c|}{ Unburned } \\
\hline & Abun. & S. rich. & Abun. & S. rich. & Abun. & S. rich. & Abun. & S. rich. \\
\hline Blattodea & 1 & 1 & 10 & 1 & - & - & - & - \\
\hline Coleoptera & 4 & 2 & 11 & 3 & 98 & 2 & 24 & 2 \\
\hline Diptera & 73 & 2 & - & - & 32 & 5 & 2 & 1 \\
\hline Hemiptera & 13 & 5 & 2 & 2 & - & - & - & - \\
\hline Hymenoptera & 456 & 12 & 396 & 12 & 151 & 13 & 55 & 7 \\
\hline Neuroptera & 1 & 1 & - & - & - & - & - & - \\
\hline Orthoptera & 2 & 1 & 3 & 2 & 1 & 1 & 2 & 1 \\
\hline Total insects & 550 & 24 & 422 & 20 & 282 & 21 & 83 & 11 \\
\hline
\end{tabular}

(Abun.: abundance; S. rich.: species richness)

The most abundant group except insects was spiders. Spiders were the only organism group caught among the Arachnida. Their abundance was higher in the unburned site in both sampling periods (Figure 3.) and it was found significantly different in the second term $(\mathrm{p}=0.003 ; \mathrm{t}=-1.328 ; \mathrm{n}=12)$. Centipedes were rare in both sampling sites. They were represented with 4 individuals in the burned site, 2 in the unburned site.

Coleoptera was a group represented with more individuals in the unburned site in the first sampling term while its abundance increased rapidly in the second term. This sharply raise in second month after fire was a result of intense colonization of Orthotomicus erosus, which belongs to Scolytinae subfamily. Its abundance was low in both burned and unburned sites a month after fire, but in the second sampling period its abundance increased sharply in the burned site $(p=0.004 ; n=12)$ (Figure 3.). Diptera was one of the most common groups caught in the burned site in both sampling terms. It was represented substantially by a species, Eumerus strigatus belonging to Syrphidae family. This species had greater abundance in the burned site whereas caught in very small number in unburned site (Figure 3.). 

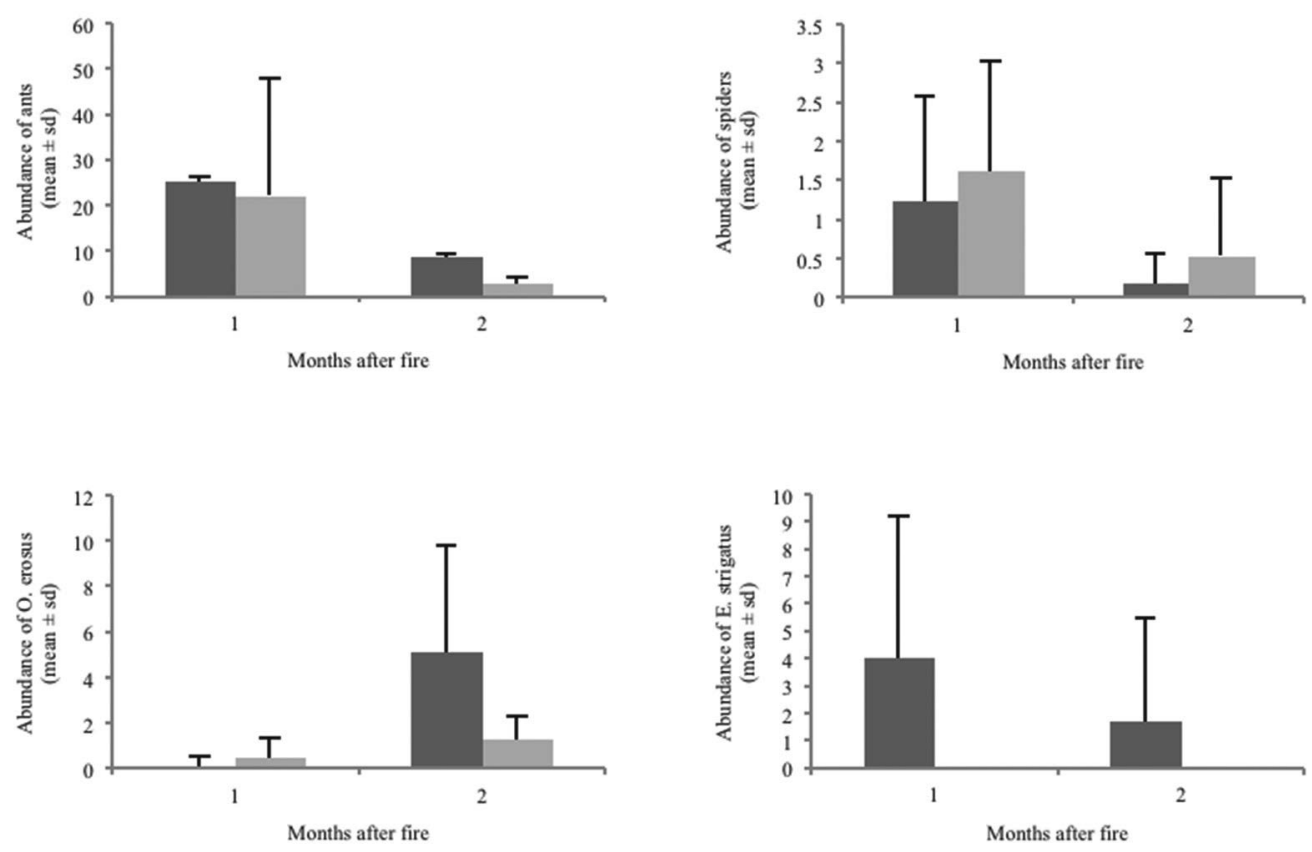

Figure 3. Abundance of common arthropod groups in the burned (darker bar) and unburned (lighter bar) sites.

Mediterranean ecosystems cope up with destructive effects of fire with high resiliency ability. In these ecosystems pre-fire species composition of plant communities are protected after fire owing to different regeneration strategies (Keeley, 1986; Trabaud, 1994). Do arthropods, as important part of this resilient ecosystem, have similar adaptive features to fire event? Compared to the boreal forest, studies in Mediterranean ecosystems regarding immediate effects of fire on arthropod communities and adaptive features evolved by arthropod species are very limited.

The post-fire faunal species composition depends on balance between survivors and immigrants. According to some studies, survivors contribute the immediate post-fire macrofaunal assemblage (Gongalsky and Persson, 2013). Beside this, in several studies it was stated that unburned forests near burned sites are generally assumed to be the most important source for colonization of some arthropod groups (Saint-Germain et al., 2008; Boulanger et al., 2010).

In this study, surface-active arthropods were monitored two months along after fire. In both sampling periods (first and second month after fire), abundances of total arthropods and insects were higher in the burned sites by comparison with unburned sites. However, this difference of the abundancy values was found more conspicuous and significant in the second sampling period. When these sampling periods are evaluated in terms of similarity, in the first term, that abundances were more close to each other, insect communities were less similar than second term. Insect communities in the burned and unburned sites became more similar in short time interval after fire. This result referred that the survivor or immigrant species used post-fire habitats were relatively different from species in mature and stabile unburned forest. After the acute phase, species composition was starting to become more stabile resembling the forest. In short time interval, increasing of similarity between burned and unburned sites provides insight about resiliency of arthropod communities to fire in Mediterranean ecosystems but for more certain evaluations future comprehensive studies are needed.

Coleoptera and Diptera orders are two groups mainly highlighted in immediate effects of fire (Wikars, 2002). Coleoptera was represented mostly by a species $O$. erosus (secondary bark beetle) infested generally recently fallen or standing trees that are under some form of stress (Mendel and Halperin, 1982). Its abundance 
displayed increase after a month especially in the burned site. Bark beetles are one of the most associated insect groups with fire (Santoro et al., 2001; McHugh et al., 2003; Santolamazza-Carbone et al., 2011; Azeria et al., 2012). After fire, burned and damaged trees consist breeding substrates for early colonizing saproxylic beetles, therefore, they are attracted to newly burned sites (Boulanger and Sirois, 2007; Boulanger et al., 2010). In addition to them, increase of abundance of $O$. erosus in the unburned site in parallel with burned site was remarkable. High activity level of $O$. erosus in the burned site was an expected result but increase of its abundance in the unburned site brings to mind its probable infestation on healthy and unburned trees close to burned sites. Secondary pests are in some cases known to act as primary pests and attack healthy trees (Fernández Fernández, 2006). Bark beetles can cause damage on healthy trees in nearby areas much more than dead and weakened trees in the burned sites (Hanula et al., 2002).

Another insect species was found associated by burned site is E. strigatus from the family Syrphidae, in the order Diptera. It is a pest species and it causes damage on bulbs of onions garlic, hyacinths, narcissi and tulips (Marcos Gerding et al., 1999). Although syrphids and the other Diptera families were recorded in high numbers in the post-fire sites (Wikars, 2002; Moretti et al., 2004), it is difficult to associate this species with fire and post-fire habitat conditions. Notwithstanding there is some information about this species has affinity to some buried materials as distinct from own host resource (Doane, 1983). From this point of view, white-colored pitfall traps could be attracted for bulb flies in darker and more simply burned habitats because white color has an attractant effect on flies (Ausden and Drake, 2006).

As one of the major surface active groups, ants are another insect group had high activation level in the burned site especially in the second sampling term. Ants are known to be affected less by fire than many other arthropod groups owing to sheltered nests against fire and adaptation to post-fire conditions (Andersen and Yen, 1985; Andersen, 1991; Jackson and Fox, 1996). The increase in activity level of ants after fire has been in question to other studies and it was interpreted as result in greater pitfall trapping effectiveness due to removal of litter and increase number of workers foraging on the ground, normally active on vegetation (Andersen and
Yen, 1985). Beside this, recovering capacity of habitat after fire is another important factor in changes of ant communities. In fire-adapted ecosystems there have been in accordance with studies about high resilience capability of ant communities (Andersen and Müller, 2000; Parr et al., 2004; Andersen et al., 2006; Arnan et al., 2006; Frizzo et al., 2012). On the other hand, in ecosystem that had a low recovering ability to fire, persistent replacement of ant species after fire was observed (Rodrigo et al., 2006).

As a result, according to this study which was performed immediately after fire, although drastic changes in community parameters of arthropod groups were found, it was not determined direct destructive effects of fire on arthropods abundance. Although more comprehensive studies are needed for certain evaluation, these results give clue recovery capability of arthropod community in Pinus brutia forest ecosystems as known high resilient to fire.

\section{ACKNOWLEDGEMENTS}

The author thanks Çağatay Tavşanoğlu and Oksal Macar for their help during the fieldwork.

\section{REFERENCES}

Andersen AN, 1991. Responses of ground-foraging ant communities to three experimental fire regimes in a savanna forest of tropical Australia. Biotropica, 23: 575-585.

Andersen AN, Müller WJ, 2000. Arthropod responses to experimental fire regimes in an Australian tropical savannah: ordinal-level analysis. Austral Ecology, 25: 199-209.

Andersen AN, Yen AL, 1985. Immediate effects of fire on ants in the semi-arid mallee region of north-western Victoria. Australian Journal of Ecology, 10: 25-30.

Andersen AN, Hertog T, Woinarski JCZ, 2006. Long-term fire exclusion and ant community structure in an Australian tropical savanna: congruence with vegetation succession. Journal of Biogeography, 33: 823-832.

Arnan X, Rodrigo A, Retana J, 2006. Post-fire recovery of Mediterranean ground ant communities follows vegetation and dryness gradients. Journal of Biogeography, 33: 12461258.

Ausden M, Drake M, 2006. Invertebrates. In: Sutherland WJ (eds) Ecological Census Techniques a handbook, 2nd edition. Cambridge University Press, Cambridge, UK, p 214-249.

Azeria ET, Ibarzabal J, Hébert C, 2012. Effects of habitat characteristics and interspecific interactions on co-occurrence patterns of saproxylic beetles breeding in tree boles after forest fire: null model analyses. Community Ecology 168, 1123-1135. 
Boulanger Y, Sirois L. 2007, Postfire succession of saproxylic arthropods, with emphasis on Coleoptera, in the north boreal forest of Quebec. Environmental Entomology, 36: 128-141.

Boulanger Y, Sirois L, Hébert C, 2010. Distribution of saproxylic beetles in a recently burned landscape of the northern boreal forest of Québec. Forest Ecology and Management, 260: 1114-1123.

Broza M, Izhaki I. 1997, Post-fire arthropod assemblages in Mediterranean forest soils in Israel. International Journal of Wildland Fire, 7: 317-325.

Doane JF, 1983. Attraction of the lesser bulb fly Eumerus strigatus (Diptera: Syrphidae) to decomposing outmeal. New Zeland Entomologist, 7(4): 419.

Fernández Fernández MM, 2006. Colonization of fire-damaged trees by Ips sexdentatus (Boerner) as related to the percentage of burned crown. Entomologica Fennica, 17: 381-386.

Fox BJ, Fox MD. 1987, The role of fire in the scleromorphic forests and shrublands of eastern Australia. In: Trabaud L (ed) The role of fire in ecological systems. S.P.B. Academic Publishers, The Hague, p. 23-48.

Frizzo TLM, Campos RI, Vasconcelos HL, 2012. Contrasting effects of fire on arboreal and ground-dwelling ant communities of a Neotropical savanna. Biotropica, 44(2): 254-261.

Gongalsky KB, Persson T, 2013. Recovery of soil macrofauna after wildfires in boreal forests. Soil Biology \& Biochemistry, 57: 182-191.

Hanula JL, Meeker JR, Miller DR, Barnard EL, 2002. Association of wildfire with tree health and numbers of pine bark beetles, reproduction weevils and their associates in Florida. Forest Ecology and Management, 170: 233-247.

Jackson GP, Fox BJ, 1996. Comparison of regeneration following burning, clearing or mineral sand mining at Tomago, NSW: II. Succession of ant assemblages in a coastal forest. Australian Journal of Ecology, 21: 200-216.

Kaynaş BY, Gürkan B, 2008. Species richness and abundance of insects during post-fire succession of a Pinus brutia forest in Mediterranean region. Polish Journal of Ecology, 56: 165-172.

Kaynaş BY, Gürkan B, 2007. Species diversity of butterflies in Turkish Pinus brutia forest ecosystems after fire. Entomological News, 118 (1): 31-39.

Keeley JE, 1986. Resilience of Mediterranean shrub communities to fires. In: Dell B, Hopkins AJM, Lamont BB (eds) Resilience in Mediterranean-type ecosystems. Dr W Junk Publishers, Dordrecht, p. 95-111.

Kim TN, Holt RD, 2012. The direct and indirect effects of fire on the assembly of insect herbivore communities: examples from the Florida scrub habitat. Oecologia, 168: 997-1012.
Marcos Gerding P, Ernesto Cisternas A, Alfonso Aguilera P, Jaime Apablaza H, 1999. Eumerus strigatus (Fallen) (Diptera: Syrphidae) infestando Alliaceae en Chile. Agricultura Técnica, 59(2): 133-135.

McHugh CW, Kolb TE, Wilson JL, 2003. Bark beetle attacks on Panderosa pine following fire in Northern Arizona. Environmental Entomology, 32(3): 510-522.

Mendel Z, Halperin J, 1982. The biology and behavior of Orthotomicus erosus in Israel. Phytoparasitica, 10(3): 169181.

Moretti M, Obrist MK, Duelli P, 2004. Arthropod biodiversity after forests fires: Winners and losers in the winter fire regime of the Southern Alps. Ecography, 27: 173-186.

Paquin P, Coderre D, 1997. Deforestation and fire impact on edaphic insect larvae and other macroarthropods. Environmental Entomology, 26: 21-30.

Parr CL, Robertson HG, Biggs HC, Chown SL, 2004. Response of African savanna ants to long-term fire regimes. Journal of Applied Ecology, 41: 630-642.

Prodon R, Fons R, Athias-Binche F, 1987. The impact of fire on animal communities in Mediterranean Area. In: Trabaud L (ed) The Role of Fire in Ecological Systems. SPA Academic Publishing, The Hague, p. 121-157.

Radea C, Arianoutsou M, 2000. Cellulose decomposition rates and soil arthropod community in a Pinus halepensis Mill. forest of Greece after wildfire. European Journal of Soil Biology, 36(1): 57-64.

Rodrigo A, Retana J, Liebhold A, 2006. Post-fire recovery of ant communities in submediterranean Pinus nigra forests Ecography, 29(2): 231-239.

Saint-Germain M, Drapeau P, Buddle CM, 2008. Persistence of pyrophilous insects in fire-driven boreal forests: population dynamics in burned and unburned habitats. Diversity and Distributions, 14: 713-720.

Saint-Germain M, Drapeau P, Hébert C, 2004. Comparison of Coleoptera assemblages from a recently burned and unburned black spruce forests of northeastern North America. Biological Conservation, 118: 583-592.

Santolamazza-Carbone S, Pestaña M, Antonio Vega J, 2011. Postfire attractiveness of maritime pines (Pinus pinaster Ait.) to xylophagous insects. . Journal of Pest Science, 84: 343-353.

Santoro AE, Lombardero MJ, Ayres MP, Ruel JJ, 2001. Interactions between fire and bark beetles in an old growth pine forest Forest Ecology and Management, 144: 245-254.

Sgardelis SP, Pantis JD, Argyropoulou MD, Stamou GP, 1995. Effects of fire on soil macroinvertebrates in a Mediterranean phryganic ecosystem. Internatio + 
